\title{
Nitrites and nitrates in exhaled breath condensate in cystic fibrosis: relation to clinical parameters
}

\author{
Fila $\mathrm{L}^{1}$, Chladek $\mathrm{J}^{2}$, Maly $\mathrm{M}^{3}$, Musil $\mathrm{J}^{4}$ \\ Pulmonary Department, Charles University, 2nd Faculty of Medicine, and University Hospital Motol, \\ Prague, Czech Republic. libor_fila@seznam.cz
}

\begin{abstract}
Objectives: To evaluate correlation of exhaled breath condensate (EBC) nitrite and nitrate concentrations with disease severity in cystic fibrosis (CF) patients.

Background: Nitrites and nitrates are products of oxidative metabolism of nitric oxide. Impaired metabolism of nitric oxide plays a role in pathogenesis of $\mathrm{CF}$.

Methods: EBC was collected from 46 stable CF patients and from 21 healthy controls. EBC concentrations of nitrites and nitrates were correlated with parameters of lung disease and nutritional status and with systemic inflammatory markers.

Results: EBC nitrates concentrations in CF patients were lower than in healthy subjects (5.8 vs $14.3 \mu \mathrm{mol} / \mathrm{l}$, $p<0.001)$. They correlated positively with $\operatorname{FEV}_{1}(p=0.025)$ and serum albumin values $(p=0.016)$ and negatively with chest radiograph Northern score $(p=0.015)$ and serum C-reactive protein values $(p=0.005)$. EBC nitrites concentrations in CF patients did not differ from those in healthy subjects and were not correlated to any studied parameter.

Conclusions: EBC nitrates concentrations correlate with disease severity in CF patients and are lower than in healthy subjects (Tab. 4, Fig. 1, Ref. 48). Full Text in PDF www.elis.sk.

Key words: cystic fibrosis, disease severity, exhaled breath condensate, nitrites, nitrates.
\end{abstract}

\begin{abstract}
Abbreviations: $\mathrm{BMI}$ - body mass index, $\mathrm{CF}$ - cystic fibrosis, $\mathrm{CRP}$ - C-reactive protein, $\mathrm{EBC}$ - exhaled breath condensate, eNO - exhaled nitric oxide, $\mathrm{FEV}_{1}$ - forced expiratory volume in first second, IgG - immunoglobulin G, iNOS - inducible nitric oxide synthase.
\end{abstract}

Bronchopulmonary disease in cystic fibrosis $(\mathrm{CF})$ is characterised by impaired mucociliary clearance, chronic bacterial infection and neutrophilic inflammation (1). Beside the dysfunction of cystic fibrosis transmembrane conductance regulator (CFTR), an impaired nitric oxide (NO) metabolism plays a role in the pathogenesis of CF (2). The values of exhaled NO (eNO) in CF adults

${ }^{1}$ Pulmonary Department, Charles University, 2nd Faculty of Medicine, and University Hospital Motol, Prague, Czech Republic, ${ }^{2}$ Department of Pharmacology, Charles University, Faculty of Medicine, Hradec Králové, Czech Republic, ${ }^{3}$ Department of Scientific Information and Biostatistics, National Institute of Public Health, Prague, Czech Republic, and ${ }^{4}$ Pulmonary Department, Hospital Mělník, Mělník, Czech Republic

Address for correspondence: L. Fila, MD, Pulmonary Department, Charles University, 2nd Faculty of Medicine, and University Hospital Motol, V Uvalu 84, CZ-150 06 Prague, Czech Republic.

Phone: +420.224436601

Acknowledgement: This work was funded by grant of Ministry of Health of Czech Republic (IGA MZCR NR/8304-3). The authors wish to thank Ms. V. Lopotova for her help with the collection of EBC and preparation of samples for analyses, Ms. V. Flegrova for lung function tests, Ms. J. Prokopova for her help with EBC analyses, and Department of Clinical Biochemistry and Pathobiochemistry of Charles University, 2nd Faculty of Medicine, Prague, Czech Republic, for analyses of inflammatory markers. are lower when compared with healthy subjects and are positively correlated with pulmonary function $(3,4,5)$.

Nitrites $\left(\mathrm{NO}_{2}^{-}\right)$and nitrates $\left(\mathrm{NO}_{3}^{-}\right)$are products of oxidative metabolism of $\mathrm{NO}$. The studies measuring $\mathrm{NO}_{2}^{-}$and $\mathrm{NO}_{3}^{-}$in sputum or bronchoalveolar lavage fluid have found either unchanged or increased concentrations of these metabolites in patients with CF compared to healthy subjects $(6,7,8,9)$. The concentrations of $\mathrm{NO}_{2}^{-}$and $\mathrm{NO}_{3}^{-}$in sputum correlated positively with pulmonary function (6).

Exhaled breath condensate (EBC) is collected by cooling of expired gas during tidal breathing. This is a non-invasive and easyto-perform method of sampling the secretions from airways (10). The concentrations of $\mathrm{NO}_{2}^{-}$in $\mathrm{EBC}$ in CF patients were similar or higher when compared with healthy controls and did not correlate with pulmonary function $(11,12)$. On the other hand, the concentrations of $\mathrm{NO}_{3}^{-}$in $\mathrm{EBC}$ were similar or lower in $\mathrm{CF}$ patients than in controls $(13,14,15)$.

In the present study, the relationships between concentrations of NO metabolites and clinical characteristics of $\mathrm{CF}$ patients were analysed by using a commercial device for EBC collection and a thoroughly validated analytical method for measurement of EBC concentrations of $\mathrm{NO}_{2}^{-}$and $\mathrm{NO}_{3}^{-}$in a large study population.

\section{Methods}

Patients with CF were consecutively recruited into the study at the Pulmonary Department of Charles University, 2nd Faculty of Medicine, and University Hospital Motol in Prague, Czech Repub- 
lic. The diagnosis of $\mathrm{CF}$ was confirmed in all patients by repeated sweat test with chloride concentration exceeding $60 \mathrm{mmol} / \mathrm{l}$ and by mutation analysis of CFTR gene. Respiratory disorders other than $\mathrm{CF}$ and smoking history were the main exclusion criteria.

The examinations were performed during routine out-patient visits in a stable phase of the disease. Demographic parameters (sex and age) and sputum microbiology (predominant bacteria) were collected from patients' records. Written informed consent was obtained from all subjects. The study was approved by Ethical Committee of Charles University, 2nd Faculty of Medicine, Prague, Czech Republic. Control healthy subjects were staff members or students with no history of smoking or any chronic lung disease.

EBC collection was performed according to ERS/ATS guidelines using ECoScreen device (Jaeger, Germany) (10). Obtained EBC was frozen immediately and stored at $-80{ }^{\circ} \mathrm{C}$ until examined. $\mathrm{EBC} \mathrm{NO}_{2}^{-}$and $\mathrm{NO}_{3}^{-}$concentrations were assayed by liquid chromatography after derivatization with diaminonaphthalene, as described previously (16). EBC collection was carried out in antemeridian hours and was preceded by chest physiotherapy early in the morning with nebulized dornase alpha. Lung function tests were completed after the collection of EBC.

Lung function tests were performed using Jaeger MasterLab device (Jaeger, Germany) according to ERS/ATS guidelines with reversibility testing (with $400 \mu \mathrm{g}$ of salbutamol) (17). Better results from pre-/postbronchodilatory values of forced expiratory volume in the first second $\left(\mathrm{FEV}_{1}\right)$ were reported. Chest radiographs were

Tab. 1. Demographic data in CF patients and in healthy controls.

\begin{tabular}{lccc}
\hline Parameter & $\begin{array}{c}\text { CF patients } \\
(\mathrm{n}=46)\end{array}$ & $\begin{array}{c}\text { Healthy } \\
\text { controls }(\mathrm{n}=21)\end{array}$ & p-value \\
\hline Age (years) & $\begin{array}{c}24.6 \\
(19.5-32.9)\end{array}$ & $\begin{array}{c}26.0 \\
(15.0-38.0)\end{array}$ & $0.246^{*}$ \\
& $23 / 23$ & $12 / 9$ & $0.610^{\S}$ \\
\hline Sex (M / F) & & & \\
\hline Sputum microbiology & $1(2.1 \%)$ & & \\
no bacteria & $5(10.9 \%)$ & & \\
$\begin{array}{l}\text { Styphylococcus aureus } \\
\text { Pseudomonas aeruginosa }\end{array}$ & $12(26.1 \%)$ & & \\
Burkholderia cepacia complex & $28(60.9 \%)$ & & \\
\hline $\begin{array}{l}\text { Age is expressed as arithmetic mean and 95\% CI; * two-sample t-test; }{ }^{\S} \text { Fisher‘s } \\
\text { exact test }\end{array}$ &
\end{tabular}

\section{Tab. 2. Clinical characteristics in CF patients}

done and scored using the Northern score (18). Body weight and body height were measured under standard conditions and body mass indexes (BMI) were calculated. Blood for routine biochemical analyses was sampled by venepuncture under standard conditions. Routine biochemical analyses, i.e. serum C-reactive protein (CRP), immunoglobulin $\mathrm{G}(\mathrm{IgG})$ and albumin were performed using standard techniques.

Data were expressed as arithmetic or geometric means (for normally or log-normally distributed data, respectively) and $95 \%$ confidence intervals (CI) for means. Comparisons between groups were made using Fisher's exact test and two-sample t-test. The values were log-transformed when the distribution of original variables was highly skewed ( $\mathrm{CRP}, \mathrm{NO}_{2}^{-}$and $\mathrm{NO}_{3}^{-}$). Evaluation of correlations between variables was made using Spearman's rank correlation coefficient $\left(\mathrm{r}_{\mathrm{s}}\right)$. A p-value $<0.05$ was considered statistically significant. Statistical software Stata, release 9 (Stata-Corp LP, College Station, TX) was used for analysis.

\section{Results}

Forty-six patients with $\mathrm{CF}$ and 21 healthy subjects were enrolled in the study. No differences were found in the demographic data between these two groups. Gram-negative bacteria, i.e. Pseudomonas aeruginosa and Burkholderia cepacia complex, predominated in sputum cultures in 40 patients (Tab. 1).

Clinical characteristics of CF patients and results of laboratory tests are presented for the whole group as well as separately for females and males. No sex-related differences were found except for lower serum albumin values in females (Tab. 2).

Concentrations of $\mathrm{NO}_{3}^{-}$were lower in $\mathrm{CF}$ patients than in healthy subjects, while the levels of $\mathrm{NO}_{2}^{-}$did not differ between these groups. Sex did not influence the EBC NO metabolites concentrations in CF patients (Tab. 3).

No significant correlation was found between $\mathrm{EBC} \mathrm{NO}_{2}^{-}$concentration and any of clinical parameters in $\mathrm{CF}$ patients. The $\mathrm{NO}_{3}^{-}$ values were correlated with several clinical characteristics. The $\mathrm{NO}_{3}^{-}$concentration correlated positively with $\mathrm{FEV}_{1}$ value and serum albumin concentration. Negative correlation was observed between $\mathrm{NO}_{3}^{-}$concentration and Northern score and also with serum CRP concentration (Tab. 4). Significant correlations are depicted in Figure 1.

\begin{tabular}{|c|c|c|c|c|}
\hline \multirow{2}{*}{ Parameter } & \multirow{2}{*}{ CF patients $(n=46)$} & \multicolumn{3}{|c|}{ Sex-specific characteristics in CF patients } \\
\hline & & Males $(n=23)$ & Females $(n=23)$ & p-value* \\
\hline$\overline{\mathrm{FEV}_{1}(\% \text { pred. })}$ & $59.1(53.2-65.0)$ & $58.4(50.8-66.0)$ & $59.8(50.3-69.4)$ & 0.810 \\
\hline Northern score & $8.0(7.1-8.8)$ & $8.1(6.9-9.3)$ & $7.9(6.6-9.2)$ & 0.802 \\
\hline $\operatorname{BMI}\left(\mathrm{kg} / \mathrm{m}^{2}\right)$ & $20.8(20.1-21.6)$ & $20.7(19.7-21.8)$ & $20.9(19.8-22.0)$ & 0.779 \\
\hline Albumin $(\mathrm{g} / \mathrm{l})$ & $42.0(41.4-42.9)$ & $43.3(42.1-44.5)$ & $40.7(39.5-41.9)$ & 0.003 \\
\hline $\mathrm{CRP}(\mathrm{mg} / \mathrm{l})$ & $8.3(5.9-11.7)$ & $8.4(5.0-13.9)$ & $8.2(5.0-13.6)$ & 0.961 \\
\hline$\underline{\operatorname{IgG}(g / l)}$ & $18.0(16.6-19.5)$ & $17.2(15.0-19.4)$ & $18.9(16.9-20.9)$ & 0.249 \\
\hline
\end{tabular}

Values are expressed as arithmetic means ( $\mathrm{FEV}_{1}$, Northern score, BMI, albumin and IgG) or geometric means (CRP) and 95\% CI; * two-sample t-test

Tab. 3. EBC concentrations of nitrites and nitrates in CF patients and in healthy controls

\begin{tabular}{|c|c|c|c|c|c|c|}
\hline \multirow[t]{2}{*}{ Parameter } & \multirow[t]{2}{*}{ Healthy controls $(n=21)$} & \multirow[t]{2}{*}{ CF patients $(n=46)$} & \multirow[t]{2}{*}{ p-value* } & \multicolumn{3}{|c|}{ Sex-specific characteristics in CF patients } \\
\hline & & & & Males $(n=23)$ & Females $(n=23)$ & p-value* \\
\hline Nitrites $(\mu \mathrm{mol} / 1)$ & $4.3(3.7-4.9)$ & $4.4(3.5-5.5)$ & 0.853 & $5.1(3.9-6.8)$ & $3.8(2.7-5.3)$ & 0.159 \\
\hline Nitrates $(\mu \mathrm{mol} / 1)$ & $14.3(10.7-19.3)$ & $5.8(4.2-7.8)$ & $<0.001$ & $6.2(4.0-9.5)$ & $5.3(3.3-8.6)$ & 0.632 \\
\hline
\end{tabular}

Values are expressed as geometric means and $95 \% \mathrm{CI} ; *$ two-sample t-test 
Tab. 4. Spearman's correlations $\left(r_{s}\right)$ between clinical characteristics of CF patients and $\mathrm{EBC}$ concentrations of nitrites and nitrates.

\begin{tabular}{lccccc}
\hline Parameter & \multicolumn{2}{c}{ Nitrites $(\mu \mathrm{mol} / \mathrm{l})$} & & \multicolumn{2}{c}{ Nitrates $(\mu \mathrm{mol} / \mathrm{l})$} \\
\cline { 2 - 3 } \cline { 5 - 6 } & $\mathrm{r}_{\mathrm{S}}$ & $\mathrm{p}$-value & & $\mathrm{r}_{\mathrm{S}}$ & $\mathrm{p}$-value \\
\hline FEV $_{1}(\%$ pred.) & 0.14 & 0.331 & & 0.33 & 0.025 \\
Northern score & -0.09 & 0.565 & & -0.36 & 0.015 \\
BMI $\left(\mathrm{kg} / \mathrm{m}^{2}\right)$ & 0.05 & 0.738 & & 0.27 & 0.068 \\
Albumin $(\mathrm{g} / \mathrm{l})$ & 0.12 & 0.423 & & 0.35 & 0.016 \\
CRP $(\mathrm{mg} / \mathrm{l})$ & -0.09 & 0.533 & & -0.40 & 0.005 \\
IgG $(\mathrm{g} / \mathrm{l})$ & -0.20 & 0.188 & & -0.21 & 0.089 \\
\hline
\end{tabular}

\section{Discussion}

$\mathrm{CF}$ is generally considered to be a disease with decreased eNO. The recent publications report eNO in CF to be similar $(19,20)$ or lower $(21,22,23)$ than in controls. Positive correlation with FEV value $(3,5,24)$ or disease severity (Shwachman-Kulczycki score) (8) is also reported.

The issues regarding eNO levels in CF seem to be different in children with early lung disease than in adults with advanced bronchopulmonary involvement. The eNO value in children is initially normal and decreases subsequently (19). Moreover, children with CF have a higher alveolar NO concentration together with
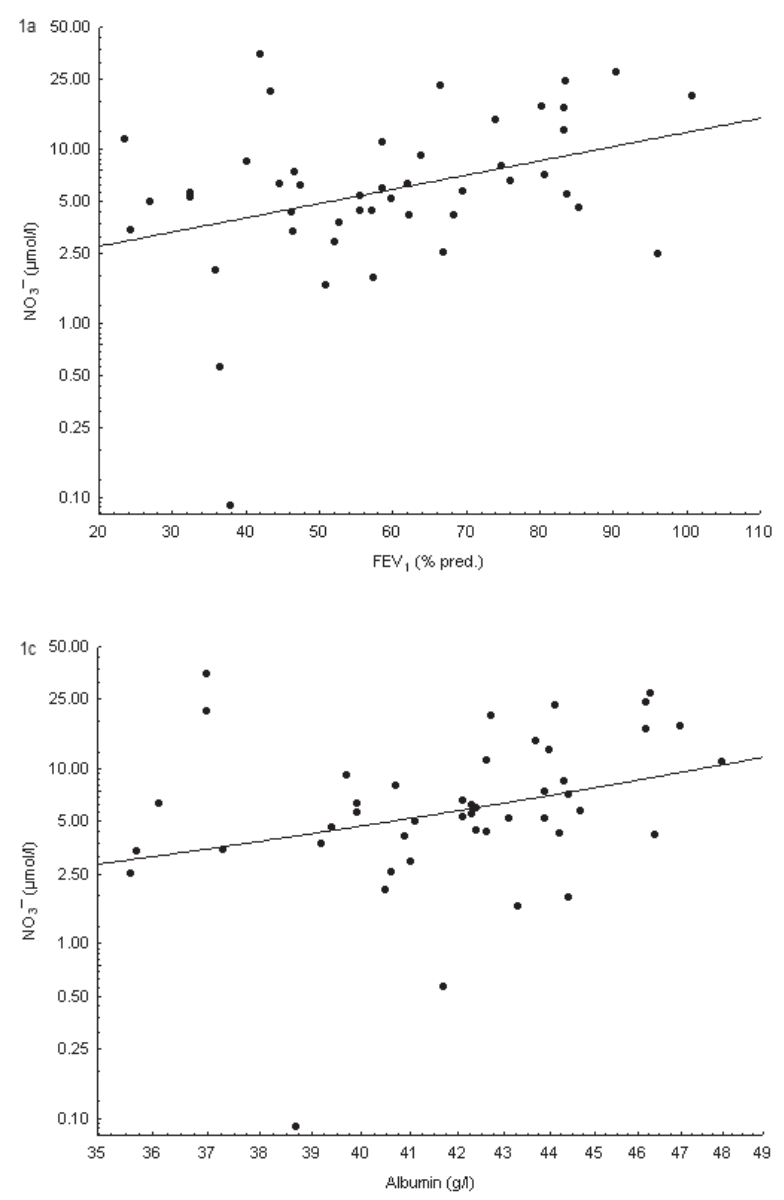

normal bronchial NO flux (20). This is confirmable with a higher macrophages count in alveoli in CF foetuses before infection (25) and with increased expression of inducible NO synthase (iNOS) in inflammatory cells (26). The expression of iNOS in airway epithelial cells is normal (9) or decreased (23).

On the other hand, alveolar NO concentration is normal and bronchial NO flux is decreased in CF adults with advanced lung disease (4). The expression of iNOS in both alveolar macrophages and airway epithelial cells decreases as the inflammation progresses and is inversely related to the neutrophils count in bronchoalveolar lavage fluid (9).

Beside iNOS, the levels of eNO are influenced by arginase activity. Arginase reduces the availability of arginine for NO synthase. Arginase activity in $\mathrm{CF}$ is higher and negatively correlated to $\mathrm{FEV}_{1}$. Antibiotic therapy reduces arginase activity in $\mathrm{CF}$ (3). Studies with oral L-arginine supplementation in CF patients were conducted. However, they showed diverse results with regard to eNO levels $(27,28)$.

A further factor taking part in lowered $\mathrm{eNO}$ in $\mathrm{CF}$ is the retention of NO in respiratory secretions. It was found that similarly to $\mathrm{FEV}_{1}$, eNO undergoes changes after dornase alpha treatment (29). In such condition, $\mathrm{NO}$ is subject of oxidative metabolism, which is increased in CF airways (30).
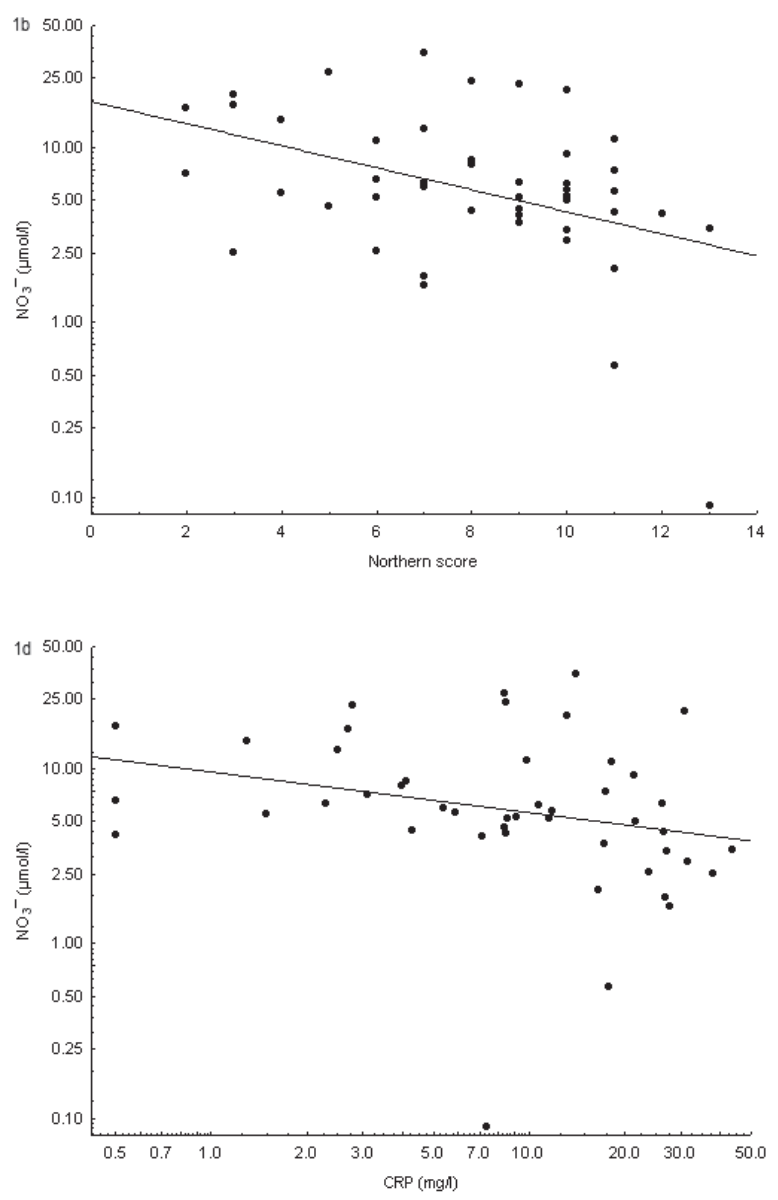

Fig. 1. Correlations between $\mathrm{EBC} \mathrm{NO}_{3}^{-}$concentration and clinical parameters in $\mathrm{CF}$ patients. Significant correlations were found between exhaled breath condensate $\mathrm{NO}_{3}{ }^{-}$concentration and $\mathrm{FEV}_{1}(1 \mathrm{a})$, Northern score (1b) and serum albumin (1c) and C-reactive protein (1d) concentration. 
503-507

We should also take into consideration the bacterial metabolism of NO in CF airways. In chronic P. aeruginosa infection, NO is reduced to ammonia (31).

The influence of alimentary $\mathrm{NO}_{2}^{-}$and $\mathrm{NO}_{3}^{-}$on eNO in $\mathrm{CF}$ is subject of conjecture. In healthy persons, diets rich in $\mathrm{NO}_{3}^{-}$lead to an increase in eNO (32). Since $80 \%$ of alimentary $\mathrm{NO}_{3}^{-}$originates in vegetables (33), we cannot exclude the influence of food on low eNO in $\mathrm{CF}$. The reason is that high-calorie, high-fat diet in CF patients may contain a low amount of vegetables. However, CF patients have higher serum concentrations of $\mathrm{NO}_{2}^{-}$and $\mathrm{NO}_{3}^{-}$than controls (26).

The issues regarding $\mathrm{NO}_{2}^{-}$and $\mathrm{NO}_{3}^{-}$concentrations in $\mathrm{EBC}$ are also complex. They include the production of $\mathrm{NO}_{2}^{-}$and $\mathrm{NO}_{3}^{-}$by oxidative metabolism of $\mathrm{NO}$ in airways together with secretion of alimentary $\mathrm{NO}_{3}^{-}$in saliva and their reduction to $\mathrm{NO}_{2}^{-}$by oropharyngeal bacteria (34). Swallowed $\mathrm{NO}_{2}^{-}$may be further reduced in acid juice in stomach to $\mathrm{NO} . \mathrm{NO}_{3}^{-}$-rich diet leads to higher eNO in healthy people, in whom both alveolar NO concentration and bronchial NO flux increase. Chlorhexidine mouthwash leads to a decrease in alveolar NO concentration at baseline and after dietary $\mathrm{NO}_{3}^{-}$load (35). In CF patients and in healthy controls, chlorhexidine mouthwash leads to a decrease in eNO and $\mathrm{EBC}$ concentration of $\mathrm{NO}_{2}^{-}$. EBC concentration of $\mathrm{NO}_{2}^{-}$positively correlates with salivary $\mathrm{NO}_{2}^{-}$concentration. Furthermore, a decrease in $\mathrm{NO}_{2}^{-}$ concentration in saliva after chlorhexidine mouthwash is coupled with an increase in $\mathrm{NO}_{3}^{-}$concentration. However, EBC concentration of $\mathrm{NO}_{3}^{-}$is not affected by oropharyngeal disinfection (15). In accordance with these findings, $\mathrm{EBC}$ concentration of $\mathrm{NO}_{2}^{-}$in $\mathrm{CF}$ patients is not correlated to pulmonary function $\left(\mathrm{FEV}_{1}\right)$, chest radiograph (Crispin-Norman score) and clinical status (modified Shwachman-Kulczycki score) and also do not predict pulmonary exacerbation (36). In our study, we obtained similar results.

There is a lack of data dealing with the relation of $\mathrm{EBC} \mathrm{NO}_{3}^{-}$ concentration and clinical and laboratory parameters in CF. In our study, we found a significant correlation of EBC concentration of $\mathrm{NO}_{3}^{-}$with pulmonary function, chest radiograph score and serum concentrations of albumin and CRP. On the basis of these results, the measurement of EBC concentration of $\mathrm{NO}_{3}^{-}$in $\mathrm{CF}$ patients seems to give more valuable information than the examination of EBC $\mathrm{NO}_{2}^{-}$concentration. However, the bacterial metabolism of $\mathrm{NO}_{3}^{-}$to $\mathrm{NO}_{2}^{-}$in lower airways (similarly to oropharyngeal tract) could contribute to a decrease in $\mathrm{NO}_{3}^{-}$concentration in $\mathrm{EBC}$. It was shown that the presence of membrane-bound nitrate reductase is critical for $P$. aeruginosa growth in CF respiratory secretions (37) and that sputum concentration of $\mathrm{NO}_{3}^{-}$increases after antibiotic treatment of pulmonary exacerbation in $\mathrm{CF}$ (7).

Correlations of EBC concentration of $\mathrm{NO}_{3}^{-}$and serum albumin and CRP may be considered surprising. Serum albumin is one of nutritional markers as well as an important antioxidant. The relation of nutritional status and NO synthase activity was studied in rats. In malnourished rats, NO synthase activity was decreased (38). Similarly, malnourished CFTR -/- mice had a decreased amount of $\mathrm{NO}_{2}^{-}$in lung tissue (39). Positive correlation of EBC concentration of $\mathrm{NO}_{3}^{-}$with serum albumin concentration could reflect higher $\mathrm{NO}$ production in persons with better nutritional status. However, we found no correlation of $\mathrm{EBC} \mathrm{NO}_{3}^{-}$concentration with BMI.
Serum CRP concentration in our CF population may be considered too high for a stable phase of disease. Nevertheless, our values correspond to data in CF adults in other studies $(40,41)$. Moreover, an airway colonisation with $P$. aeruginosa and/or $B$. cepacia complex was present in our study group in $87 \%$ of subjects and measurements in such groups of CF adults by others give similar data $(42,43)$. The information about relations of EBC concentration of both $\mathrm{NO}_{2}^{-}$and $\mathrm{NO}_{3}^{-}$with systemic inflammatory markers is sparse. For example, Ho and co-workers found a positive correlation of $\mathrm{EBC} \mathrm{NO}_{2}^{-}$concentration and circulating plasma leukocytes and neutrophils (44). In our study, the negative correlation of $\mathrm{EBC} \mathrm{NO}_{3}^{-}$concentration and serum CRP concentration probably reflects the systemic inflammatory response to the severity of bronchopulmonary involvement or above mentioned airway colonisation with typical gramnegative bacteria $(45,46)$.

EBC concentrations of $\mathrm{NO}_{2}^{-}$and $\mathrm{NO}_{3}^{-}$in healthy subjects observed in our study were in excellent agreement with the results of other investigators obtained using the same collection device and analytical method $(47,48)$.

In summary, $\mathrm{EBC} \mathrm{NO}_{3}^{-}$concentrations correlate with disease severity in CF patients and are lower than in healthy subjects.

\section{References}

1. Boucher RC. New concepts of the pathogenesis of cystic fibrosis lung disease. Eur Respir J 2004; 23 (1): 146-158.

2. de Winter-de Groot KM, van der Ent CK. Nitric oxide in cystic fibrosis. J Cyst Fibros 2005; 4 (Suppl 2): 25-29

3. Grasemann H, Schwiertz R, Matthiesen S, Racke K, Ratjen F. Increased arginase activity in cystic fibrosis airways. Am J Respir Crit Care Med 2005; 172 (12): 1523-1528.

4. Hofer M, Mueller L, Rechsteiner T, Benden C, Boehler A. Extended nitric oxide measurements in exhaled air of cystic fibrosis and healthy adults. Lung 2009; 187 (5): 307-313.

5. Ojoo JC, Mulrennan SA, Kastelik JA, Morice AH, Redington AE. Exhaled breath condensate $\mathrm{pH}$ and exhaled nitric oxide in allergic asthma and in cystic fibrosis. Thorax 2005; 60 (1): 22-26.

6. Cetin I, Ozcelik U, Gocmen A, Kiper N, Dogru D, Yalcin E. BALF nitrite as an indicator of inflammation in children with cystic fibrosis. Respiration 2004; 71 (6): 625-629.

7. Grasemann H, Ioannidis I, Tomkiewicz RP, de Groot H, Rubin BK, Ratjen F. Nitric oxide metabolites in cystic fibrosis lung disease. Arch Dis Child 1998; 78 (1): 49-53.

8. Robroeks CM, Rosias PP, van Vliet D et al. Biomarkers in exhaled breath condensate indicate presence and severity of cystic fibrosis in children. Pediatr Allergy Immunol 2008; 19 (7): 652-659.

9. Wooldridge JL, Deutsch GH, Sontag MK et al. NO pathway in CF and non-CF children. Pediatr Pulmonol 2004; 37 (4): 338-350.

10. Horvath I, Hunt J, Barnes PJ et al. ATS/ERS Task Force on Exhaled Breath Condensate. Exhaled breath condensate: methodological recommendations and unresolved questions. Eur Respir J 2005; 26 (3): 523-548.

11. Balint B, Kharitonov SA, Hanazawa $T$ et al. Increased nitrotyrosine in exhaled breath condensate in cystic fibrosis. Eur Respir J 2001; 17 (6): 1201-1207. 
12. Corradi M, Montuschi P, Donnelly LE, Pesci A, Kharitonov SA, Barnes PJ. Increased nitrosothiols in exhaled breath condensate in inflammatory airway diseases. Am J Respir Crit Care Med 2001; 163 (4): 854-858.

13. Fila L, Musil J, Valentová Bartáková L, Chládek J. The impact of inhaled corticosteroids treatment on exhaled breath condensate in cystic fibrosis patients. Stud Pneumol Phthiseol 2008; 68 (1): 6-9.

14. Griese M, Noss J, Schramel P. Elemental and ion composition of exhaled air condensate in cystic fibrosis. J Cyst Fibros 2003; 2 (3): 136-142.

15. Zetterquist W, Marteus H, Kalm-Stephens P et al. Oral bacteria--the missing link to ambiguous findings of exhaled nitrogen oxides in cystic fibrosis. Respir Med 2009; 103 (2): 187-193.

16. Chládková J, Krčmová I, Chládek J, Čáp P, Mičuda S, Hanzálková Y. Validation of nitrite and nitrate measurements in exhaled breath condensate. Respiration 2006; 73 (2): 173-179.

17. Miller MR, Hankinson J, Brusasco $\mathbf{V}$ et al. ATS/ERS Task Force. Standardisation of spirometry. Eur Respir J 2005; 26 (2): 319-338.

18. Conway SP, Pond MN, Bowler I et al. The chest radiograph in cystic fibrosis: a new scoring system compared with the Chrispin-Norman and Brasfield scores. Thorax 1994; 49 (9): 860-862.

19. Franklin PJ, Hall GL, Moeller A, Horak F Jr, Brennan S, Stick SM. Exhaled nitric oxide is not reduced in infants with cystic fibrosis. Eur Respir J 2006; 27 (2): 350-353.

20. Suri R, Paraskakis E, Bush A. Alveolar, but not bronchial nitric oxide production is elevated in cystic fibrosis. Pediatr Pulmonol 2007; 42 (12): 1215-1221.

21. Gabriele C, Nieuwhof EM, Van Der Wiel EC et al. Exhaled nitric oxide differentiates airway diseases in the first two years of life. Pediatr Res 2006; 60 (4): 461-465.

22. Keen C, Olin AC, Edentoft A, Gronowitz E, Strandvik B. Airway nitric oxide in patients with cystic fibrosis is associated with pancreatic function, Pseudomonas infection, and polyunsaturated fatty acids. Chest 2007; 131 (6): 1857-1864.

23. Moeller A, Horak F Jr, Lane C et al. Inducible NO synthase expression is low in airway epithelium from young children with cystic fibrosis. Thorax 2006; 61 (6): 514-520.

24. Hubert D, Aubourg F, Fauroux B et al. Exhaled nitric oxide in cystic fibrosis: relationships with airway and lung vascular impairments. Eur Respir J 2009; 34 (1): 117-124.

25. Hubeau C, Puchelle E, Gaillard D. Distinct pattern of immune cell population in the lung of human fetuses with cystic fibrosis. J Allergy Clin Immunol 2001; 108 (4): 524-529.

26. Morrissey BM, Schilling K, Weil JV, Silkoff PE, Rodman DM. Nitric oxide and protein nitration in the cystic fibrosis airway. Arch Biochem Biophys 2002; 406 (1): 33-39.

27. Everard ML, Donnelly D. A pilot study of oral L-arginine in cystic fibrosis. J Cyst Fibros 2005; 4 (1): 67-69.

28. Grasemann H, Grasemann C, Kurtz F, Tietze-Schillings G, Vester U, Ratjen F. Oral L-arginine supplementation in cystic fibrosis patients: a placebo-controlled study. Eur Respir J 2005; 25 (1): 62-68.

29. Grasemann H, Lax H, Treseler JW, Colin AA. Dornase alpha and exhaled NO in cystic fibrosis. Pediatr Pulmonol 2004; 38 (5): 379-385.

30. Paredi P, Kharitonov SA, Barnes PJ. Analysis of expired air for oxidation products. Am J Respir Crit Care Med 2002; 166 (12): S31-S37.
31. Gaston B, Ratjen F, Vaughan JW et al. Nitrogen redox balance in the cystic fibrosis airway: effects of antipseudomonal therapy. Am J Respir Crit Care Med 2002; 165 (3): 387-390.

32. Vints AM, Oostveen E, Eeckhaut G, Smolders M, De Backer WA. Time-dependent effect of nitrate-rich meals on exhaled nitric oxide in healthy subjects. Chest 2005; 128 (4): 2465-2470.

33. Hord NG, Tang Y, Bryan NS. Food sources of nitrates and nitrites: the physiologic context for potential health benefits. Am J Clin Nutr 2009; 90 (1): 1-10.

34. Marteus H, Tornberg DC, Weitzberg E, Schedin U, Alving K. Origin of nitrite and nitrate in nasal and exhaled breath condensate and relation to nitric oxide formation. Thorax 2005; 60 (3): 219-225.

35. Malinovschi A, Janson C, Holm L, Nordvall L, Alving K. Basal and induced NO formation in the pharyngo-oral tract influences estimates of alveolar NO levels. J Appl Physiol 2009; 106 (2): 513-519.

36. Horak F Jr, Moeller A, Singer F et al. Longitudinal monitoring of pediatric cystic fibrosis lung disease using nitrite in exhaled breath condensate. Pediatr Pulmonol 2007; 42 (12): 1198-1206.

37. Palmer KL, Brown SA, Whiteley M. Membrane-bound nitrate reductase is required for anaerobic growth in cystic fibrosis sputum. J Bacteriol 2007; 189 (12): 4449-4455.

38. Wu G, Flynn NE, Flynn SP, Jolly CA, Davis PK. Dietary protein or arginine deficiency impairs constitutive and inducible nitric oxide synthesis by young rats. J Nutr 1999; 129 (7): 1347-1354.

39. Yu H, Nasr SZ, Deretic V. Innate lung defenses and compromised Pseudomonas aeruginosa clearance in the malnourished mouse model of respiratory infections in cystic fibrosis. Infect Immun 2000; 68 (4): 2142-2147.

40. Dufresne V, Knoop C, Van Muylem A et al. Effect of systemic inflammation on inspiratory and limb muscle strength and bulk in cystic fibrosis. Am J Respir Crit Care Med 2009; 180 (2): 153-158.

41. Fischer R, Simmerlein R, Huber RM, Schiffl H, Lang SM. Lung disease severity, chronic inflammation, iron deficiency, and erythropoietin response in adults with cystic fibrosis. Pediatr Pulmonol 2007; 42 (12): 1193-1197.

42. Hendry J, Nixon L, Dodd M et al. Pulmonary function, serum markers of inflammation, and IgG antibodies to core lipopolysaccharide of Burkholderia cepacia in adults with cystic fibrosis, following colonization with Burkholderia cepacia. Pediatr Pulmonol 2000; 29 (1): 8-10.

43. Jones AM, Martin L, Bright-Thomas RJ et al. Inflammatory markers in cystic fibrosis patients with transmissible Pseudomonas aeruginosa. Eur Respir J 2003; 22 (3): 503-506.

44. Ho LP, Innes JA, Greening AP. Nitrite levels in breath condensate of patients with cystic fibrosis is elevated in contrast to exhaled nitric oxide. Thorax 1998; 53 (8): 680-684.

45. Levy H,Kalish LA. HuntingtonIetal. Inflammatorymarkers oflungdisease in adult patients with cystic fibrosis. Pediatr Pulmonol 2007; 42 (3): 256-262.

46. Wolter J, Seeney S, Bell S, Bowler S, Masel P, McCormack J. Effect of long term treatment with azithromycin on disease parameters in cystic fibrosis: a randomised trial. Thorax 2002; 57 (3): 212-216.

47. Balint B, Donnelly LE, Hanazawa T, Kharitonov SA, Barnes PJ. Increased nitric oxide metabolites in exhaled breath condensate after exposure to tobacco smoke. Thorax 2001; 56 (6): 456-461.

48. Csoma Z, Bush A, Wilson NM et al. Nitric oxide metabolites are not reduced in exhaled breath condensate of patients with primary ciliary dyskinesia. Chest 2003; 124 (2): 633-638.

Received August 16, 2011. Accepted November 30, 2011. 